\title{
Prospective Science Teachers' Views of Nature of Science: Data from an Intervention Programme
}

\author{
Joana Torres ${ }^{1^{*}}$, Clara Vasconcelos ${ }^{1,2}$ \\ ${ }^{1}$ Instituto de Ciências da Terra (ICT), PORTUGAL \\ 2 Faculdade de Ciências da Universidade do Porto, PORTUGAL
}

Received 17 April 2019 - Revised 10 June 2019 • Accepted 18 July 2019

\begin{abstract}
The development of informed views of nature of science is considered to be a crucial aim for science education. This study assesses Portuguese prospective science teachers' views of the nature of science before and after an intervention programme that took place in the first year of their master. Nine prospective science teachers that will teach biology and geology in middle and high schools voluntarily participated in this study. Pre and post questionnaires, interviews and lesson plans were analysed. Results show that prospective science teachers improved their views of nature of science. However, some of them still struggled with some aspects, which stresses the need for a better understanding of the factors that influence science teachers' views of nature of science. Despite the positive results, more research is needed to understand the factors that mediate teachers' views into their instructional practice, namely by observing and monitoring teachers' practices and work environment.
\end{abstract}

Keywords: intervention programme, models, nature of science, science education, science teachers' views

\section{INTRODUCTION}

The development of students' informed views of nature of science (NOS) is internationally considered to be a crucial goal for science education (Abd-El-Khalick, 2006; Deng, Chen, Tsai, \& Chai 2011; Lederman, Abd-El-Khalick, Bell, \& Schwartz 2002). In fact, the development of students' views about NOS is considered to be a fundamental component of any school science curriculum in Europe, given the relevance of NOS knowledge in allowing citizens to be critical and to engage with socio-scientific issues requires (Hazelkorn et al., 2015; Osborne \& Dillon, 2008). In Portugal, the science education standard documents also highlight the relevance of developing informed views of NOS, in order to assure that students become critical, literate and active (Torres \& Vasconcelos, 2015). There are many reasons that justify the inclusion of NOS instruction in science classes. For example, NOS knowledge is considered to be an important component in developing students' science literacy (Lederman, Bartos, \& Lederman, 2014; McComas, Clough, \& Almzroa, 1998; Moutinho, Torres, Fernandes, \& Vasconcelos, 2015) and some studies also reveal that a better knowledge of NOS is positively related to conceptual learning in science (Bell, 2006; Cheng \& Lin, 2015; Deng et al., 2011; McComas et al., 1998). Moreover, the knowledge of NOS is related to the enhancement of informed decision-making (Khishfe, 2012; Koksal, Cakiroglu, \& Geban 2013) and contributes to the understanding of how science operates and to the promotion of interest in science (McComas et al., 1998).

Despite the relevance that is attributed to NOS in science education, it is generally shown that students (Bell, Blair, Crawford, \& Lederman, 2003; Koksal et al., 2013; Lederman, 2007) and even teachers (Bell, Mulvey, \& Maeng, 2016; Lederman, 2007; Wahbeh \& Abd-El-Khalick, 2014) do not hold informed views of NOS. Furthermore, AbdEl-Khalick et al. (1998) also concluded that even when teachers reveal adequate understandings of some aspects of NOS, they gave little relevance to its teaching. In fact, "teachers do not regard NOS as an instructional outcome of equal status with that of 'traditional' subject matter outcomes" (Lederman, 2007, p. 869).

Although there is no direct translation between teachers' views of NOS and their instructional practice, improving teachers' views of NOS is fundamental, as it is not a sufficient, but a necessary, condition to instruct

(C) 2020 by the authors; licensee Modestum Ltd., UK. This article is an open access article distributed under the terms and conditions of the Creative Commons Attribution License (http://creativecommons.org/licenses/by/4.0/). \joana.torres@fc.up.pt (*Correspondence) $₫$ csvascon@fc.up.pt 


\section{Contribution of this paper to the literature}

- This paper analyses the effectiveness of an intervention programme to improve science teachers' views of nature of science.

- It presents an intervention programme where models play a major role for a better understanding of nature of science.

- In general, prospective science teachers improved their views concerning almost all aspects of nature of science. There are some exceptions that must be analysed.

NOS (Abd-El-Khalick, Bell, \& Lederman, 1998; Bell, Matkins, \& Gansneder, 2011). Having the aforementioned aspects in mind, we consider it fundamental to deepen prospective science teachers' views of NOS. However, it is also our aim to make them aware of the relevance of NOS and of how to teach NOS in science classes, in an attempt to contribute to an explicit-reflective approach of NOS.

\section{THEORETICAL BACKGROUND}

Although there is a lack of complete agreement regarding the definition of NOS (Abd-El-Khalick et al. 1998; Irzik and Nola 2014), there is also a significant degree of consensus amongst the members of the science education community (such as, Abd-El-Khalick, 2006; Lederman et al., 2002) regarding the definition of NOS and which aspects should be taught in schools for pre-university level (Irzik \& Nola, 2014; Kaya \& Erduran, 2016). In fact, this view of NOS is considered to be not controversial, accessible and fundamental for secondary students, being widespread accepted and an appropriate starting point for students and for science teachers in developing an authentic picture of science (Torres \& Vasconcelos, 2015). Having this in mind, we have adopted this consensus view, which is related to the characteristics of the scientific knowledge that derived from the manner in which the knowledge is developed (Lederman \& Lederman, 2014). As a result, scientific knowledge is considered to be empirical (i.e. based on and/or derived from observations of the natural world that depend on our perceptions, instrumentations and theoretical frameworks), tentative (i.e. scientific knowledge - facts, theories and even laws is subject to change, based on new information or perspectives) and partially subjective (i.e. it depends on the particular scientist's background, beliefs, training, aims and experiences). The distinction between observation and inferences is also considered to be an important aspect of NOS to be taught, as both inferences and observations are fundamental in scientific knowledge construction, as well as the distinction between theories and laws. In fact, observations are directly accessible to our senses, while inferences are not, being statements about phenomena that result of explanations or models (Abd-El-Khalick, 2006; Lederman et al., 2002). Theories and laws are both legitimate products of science, being different kinds of knowledge. While laws are generalizations, principles or patterns in nature, theories are consistent systems of explanations, playing a crucial role in guiding future research (Abd-El-Khalick, 2006; Lederman et al., 2002; McComas, 1998).

Furthermore, scientific knowledge is considered to be influenced by the creativity and imagination of scientists, and to be both influenced by and an influence on our society and culture. The understanding that no single scientific method is applied universally is also considered to be relevant, as well as the recognition of the validity of scientific disciplines that are observational in nature (Abd-El-Khalick, 2006; Lederman et al., 2002).

Although NOS instruction remains a challenging undertaking, several studies demonstrate that an explicit and reflective NOS instruction is an effective way to improve NOS views (Akerson, Abd-El-Khalick, \& Lederman, 2000; Koksal, Cakiroglu, \& Geban, 2013; Mesci \& Schwartz, 2017; Wahbeh \& Abd-El-Khalick, 2014). Contrary to an implicit approach, where NOS views are supposed to be developed while undertaking scientific inquiry activities, an explicit and reflective approach implies the development of activities with the clear intention of teaching NOS aspects and that prompt opportunities to reflect on those aspects (Akerson, Abd-El-Khalick, \& Lederman, 2000; Khishfe \& Abd-El-Khalick, 2002). Moreover, the use of history of science is helpful for students to better understand NOS, making it possible to prompt an explicit and reflective NOS instruction (Acevedo-Díaz, García-Carmona, \& Aragón, 2016; Pavez, Vergara, Santibañez, \& Cofré, 2016; Torres \& Vasconcelos, 2015). History of science may be used in many different ways and by resorting to different activities and strategies (Pavez et al., 2016). In our study we mainly rely on historical models (for example, by analysing the evolution of Earth's internal structure model), as well as historical episodes and complementary activities, to teach NOS to Portuguese prospective science teachers. Currently, it is considered to be crucial to use models in science education as they facilitate the development of accurate mental models and a better understanding of scientific concepts. Moreover, as models are fundamental in scientific activity, models are also relevant for students to develop their NOS views and inquiry skills, while having an active role in their learning (Oh \& Oh, 2011; Torres \& Vasconcelos, 2017). In fact, by constructing, using, evaluating and revising their own models, students can better understand how scientists work, apart from developing inquiry skills (Kenyon, Davis, \& Hug, 2011). Also, by understanding the nature of models 
(namely the tentativeness of models, which may be influenced, for example, by the historical context) students better understand the characteristics of the scientific knowledge and how it is developed.

As claimed by Herman and Clough (2016), science teachers must have a strong knowledge regarding science, as well as regarding NOS. However, many studies show that science teachers do no hold informed views of NOS (Bell et al., 2016; Lederman, 2007; Pavez et al., 2016; Wahbeh \& Abd-El-Khalick, 2014). For example, in studies conducted in Portugal, it was found that secondary science students and both in-service and preservice science teachers hold uniformed views regarding some NOS aspects (Torres \& Vasconcelos, 2015; Torres, Moutinho \& Vasconcelos, 2015). In these studies, it was emphasized their lack of knowledge regarding the tentativeness of scientific knowledge and the differences between theories and laws. Given the uninformed views that both Portuguese students and Portuguese science teachers hold concerning NOS and given the relevance that is attributed to the development of students' informed views of NOS, we consider it fundamental to give a contribution in the improvement of teachers and students NOS views. In this study, we intend to develop science teachers' views as a primary step in promoting an efficient NOS instruction.

\section{RESEARCH QUESTIONS}

The purpose of this study was to examine if prospective science teachers improve their views of NOS after attending the intervention programme. Below, we present the research questions that guided our study:

(i) Did prospective science teachers improve their views of specific aspects of NOS, after attending the intervention programme?

(ii) How do prospective science teachers plan to teach NOS aspects in science classes?

\section{METHODS}

This study is part of a broader research project which mainly aims to improve prospective science teachers' views of NOS and models (so as to contribute to an efficient and explicit NOS instruction, as well as an appropriate and extensive use of models in their future teaching practices) and to understand the factors that mediate the translation of teachers' views into their practices in classes.

Bearing in mind the former aim, we developed and applied an intervention programme entitled "Scientific models, modelling and nature of science in science teaching", which was briefly described below and fully described in Torres and Vasconcelos (2016a). To evaluate if this intervention programme was effective in improving prospective teachers' views concerning NOS, we analysed their answers to the questionnaires and interviews that were administered before and after the intervention programme and we also analysed their lesson plans that were constructed individually at the end of the intervention programme - a deep analysis of prospective science teachers' knowledge about models was carried out in another study (Torres \& Vasconcelos, 2017). This study relied on a qualitative approach and data was analysed with the help of the Q.S.R. NVivo 10 qualitative data analysis package.

\section{Participants}

The targeted participants consisted of all the prospective science teachers ( $n=9)$ enrolled in the Master's in Biology and Geology Teaching of a public university in the north of Portugal, a degree which will enable them to teach biology and geology subjects in middle and high schools. In Portugal, these teachers teach both biology and geology subjects. Moreover, in Portuguese science education standard documents it is recommended that these teachers should not only teach scientific content, but also promote the development of epistemological knowledge in biology and geology classes.

All of them already hold a bachelor's degree, either in biology or geology, or even in both biology and geology. In fact, in order to enrol in the aforementioned master's program, students must complete some subjects related to geology along with their BSc degree in biology or some subjects related to biology along with their BSc degree in geology. In the first year of their master's study, the students attend classes of educational sciences subjects, namely biology and geology education, psychology, ethics and also of scientific (biology and geology) subjects. The second year of the program is devoted to internship in schools, and prospective science teachers only attend a few classes in the university. Before this master, prospective science teachers have the same educational background as biologists and geologists that pursue a scientific career. In the biology course, students attend several lectures which are complemented with laboratory classes. In the geology course students also attend lectures that are complemented not only with laboratory classes, but also with several field trips. Both biology and geology courses comprise scientific subjects and do not include subjects that prompt the development of epistemological knowledge. 
All of the prospective science teachers voluntarily participated in this study and are designated by fictional names: Maria, Vera, Andreia, Bárbara, Sofia, Francisco, Carolina, Inês and Rita. Our sample comprises eight females and one male, with ages ranging from 21 to 38 (average $=23.89$ and mode $=21$ ). These nine participants consist of all prospective science teachers enrolled in this master in the north of Portugal.

\section{Procedures}

With the aim of improving prospective science teachers' views of NOS and models, we prepared and implemented an intervention programme. The intervention programme was organized in five classes, of five hours each (Torres \& Vasconcelos, 2016a). The classes took place from the end of April until the beginning of June (six weeks in total, with a one-week break, for prospective science teachers to have time to prepare their final work).

This intervention programme started with a problematic scenario, which aims to stimulate prospective science teachers to better understand the characteristics and roles of scientific models (first class). When it comes to NOS knowledge, it was mostly important to understand what scientific models are, the relevance of scientific models in the construction of scientific knowledge and the relation between scientific models and scientific theories.

After understanding what scientific models are, it was intended (in the second class) that prospective science teachers understand the role of models for teaching, namely the role of models in the learning of science, of how to do science and about science (Justi \& Gilbert, 2002, 2003). For that purpose, modelling activities were conducted and some discussions were held concerning those activities, about models in science and models for teaching and about science. In fact, after experiencing different modelling activities, they were asked to discuss some questions related to the definition of scientific models, to the purpose of using models in science, to the relation between a model and its target, to what should be included in a scientific model, to the existence of different models to represent the same target, to the change of a model and to the relevance of using models in science classes.

Afterwards (in the third class), the analysis of the historical evolution of Earth's structure model was held for prospective science teachers to recognise the relevance of historical models as contributors to the understanding of the NOS aspects, as well as to deepen their own knowledge regarding models' nature and all the NOS aspects mentioned in the theoretical background. By analysing three main documents and performing complementary activities, it was intended that prospective science teachers developed their views regarding the dynamism, subjectivity, tentativeness and empirical character of scientific knowledge; the relevance of imagination and creativity in science; and some aspects related to models' nature and function. Moreover, it was intended that they understood different aspects that influenced knowledge development, namely religion; that there is no unique scientific method, as well as the difference between theories and laws and between observations and inferences. In addition to the analysis of the documents and the discussion that was held in order to focus all the NOS aspects described in the theoretical background, some complementary activities were developed in order to promote a better understanding of NOS. For example, by relying on the inferences that Cadell (a geologist that studied the formation of mountains) made based on his experimental models, it was intended that prospective science teachers better understood what an inference is and the difference between observations and inferences. Other complementary activities, which included analysis of images, the viewing of a documentary, discussion of some paradigmatic examples, like the classification of intriguing microorganisms (Planctomycetes), and the analysis of scientific news that challenge the currently accepted knowledge, were conducted concerning the subjectivity and tentativeness in science. Other complementary activities related with the analysis of scientific theories and laws were held to promote a better understanding of the difference between theories and laws and the relevance of imagination and creativity in science. In the last complementary activity, some fundamental characteristics of science were discussed, by adapting "the mystery cubes" activities developed by Lederman and Abd-El-Khalick (1998). It was highlighted that science is characterised by a search of patterns, that were based on evidences, but that also results from inferences and from scientists' imagination and creativity.

At the end of this class, it was discussed the importance for students to develop informed views of NOS and also the importance of its teaching in an explicit, embedded and reflective way (Torres \& Vasconcelos, 2016a).

After developing prospective science teachers' knowledge regarding NOS, models in science and models for teaching, it was intended (in the fourth class) that they critically analyse how science (biology and geology) standard documents and different biology and geology textbooks recommend and cover the nature of science, models and modelling activities. It was also analysed an activity to prompt a discussion concerning the characteristics of good analogies and models, the advantages of their use in science classes, as well as the precautions to take when using them. In the end, prospective science teachers were asked to construct one lesson plan and associated didactic materials in order to apply all the concepts that were developed during the intervention programme. (They were free to choose a scientific theme, but they have to teach NOS and use models.) As a result, in the fifth class, prospective science teachers presented their final work. The intervention programme (Table 1), which is fully described in Torres and Vasconcelos (2016a), was conducted by the first author of this 
Table 1. Description of the intervention programme (main objectives and activities developed)

\begin{tabular}{|c|c|c|}
\hline Class & Main objectives & Main activities developed \\
\hline 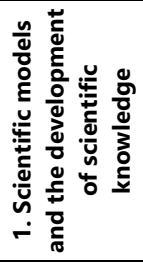 & $\begin{array}{l}\text { (i) To understand what scientific } \\
\text { models are and with which purpose } \\
\text { they are used in science. } \\
\text { (ii) To realise the relevance of } \\
\text { modelling in science, namely, in } \\
\text { geology. } \\
\text { (learning about science) }\end{array}$ & $\begin{array}{l}\text { a) Analysis of relevant papers like those of Oh and Oh (2011), Chamizo (2013) and Giere } \\
\text { (2010). } \\
\text { b) Prospective science teachers collaboratively respond to some questions related to the } \\
\text { understanding of scientific models and their role in science. } \\
\text { c) Analysis and discussion of a PowerPoint presentation in order to prompt the } \\
\text { understanding of scientific model contributions in the development of scientific areas. } \\
\text { d) Resolution of a final worksheet to analyse and classify different models according to } \\
\text { specific typologies of models. }\end{array}$ \\
\hline 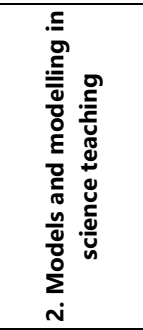 & $\begin{array}{l}\text { (iii) To understand the importance of } \\
\text { models and modelling activities as } \\
\text { contributors to the development of } \\
\text { accurate mental models and to the } \\
\text { understanding of scientific activity and } \\
\text { of the nature of science. } \\
\text { (learning of science; of how to do } \\
\text { science and about science) }\end{array}$ & $\begin{array}{l}\text { e) Prospective science teachers were encouraged to represent their own mental model } \\
\text { about Earth's structure models through a drawing, its explanation and a concept map. } \\
\text { f) Prospective science teachers experienced different modelling activities (with physical } \\
\text { but also with digital models). } \\
\text { g) Prospective science teachers were explicitly asked about the activities they conducted } \\
\text { and about models in science. With the intention to explicitly develop prospective } \\
\text { science teachers' knowledge about science, they were asked to discuss and answer } \\
\text { some questions. } \\
\text { h) A final discussion was held regarding all the advantages of models and modelling in } \\
\text { science classes. }\end{array}$ \\
\hline 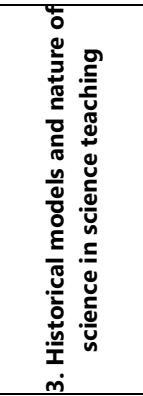 & $\begin{array}{l}\text { (iv) To recognise the relevance of } \\
\text { resorting to historical models in order } \\
\text { to promote the understanding of } \\
\text { different aspects of nature of science. } \\
\text { (v) To reflect on how to teach nature of } \\
\text { science aspects and on the importance } \\
\text { for students to develop accurate views } \\
\text { of nature of science. } \\
\text { (learning about science and of } \\
\text { science) }\end{array}$ & $\begin{array}{l}\text { i) Prospective science teachers were asked to analyse three main documents about the } \\
\text { historical evolution of Earth's structure models from the sixth century B.C. to the } \\
\text { twenty-first century. } \\
\text { j) After the analysis of the texts, prospective science teachers were asked to discuss, } \\
\text { reflect and respond to some questions about science. } \\
\text { k) Some complementary activities were also developed in order to better understand } \\
\text { different aspects of NOS. Those included the analysis of images, the viewing of a } \\
\text { documentary and discussion of some paradigmatic examples, as well as the activity } \\
\text { "mysterious cubes", which was adapted from Lederman \& Abd-El-Khalick (1998). } \\
\text { 1) At the end of this class, a discussion was held on the relevance of teaching NOS } \\
\text { aspects and also the importance of its teaching in an explicit, embedded and } \\
\text { reflective way. }\end{array}$ \\
\hline 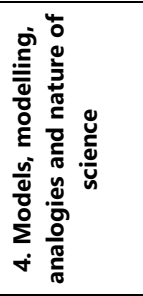 & $\begin{array}{l}\text { (vi) To understand the advantages and } \\
\text { precautions to take when using models } \\
\text { and analogies in science classes. } \\
\text { (vii) To analyse how textbooks and the } \\
\text { science (biology and geology) standard } \\
\text { documents cover nature of science, } \\
\text { models and modelling activities. } \\
\text { (learning of science; of how to do } \\
\text { science and about science) }\end{array}$ & $\begin{array}{l}\text { m) Prospective science teachers analysed Biology and Geology curricula of the 10th and } \\
11 \text { th grade (secondary school), in order to examine the suggestions and } \\
\text { recommendations provided concerning models and nature of science. } \\
\text { n) Analysis of an activity that relies on an analogical comparison. It was prompted the } \\
\text { discussion concerning the use of analogies and models in science classroom, } \\
\text { emphasising positive and negative aspects of their use, the characteristics of good } \\
\text { analogies and models as well as the precautions to take when using them. } \\
\text { o) Critical analysis and comparison of different textbooks, concerning models and nature } \\
\text { of science. }\end{array}$ \\
\hline 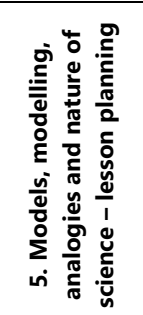 & $\begin{array}{l}\text { (viii) To apply all the concepts } \\
\text { developed in the construction of } \\
\text { didactic materials and lessons plans } \\
\text { and to justify their options. } \\
\text { (learning of science; of how to do } \\
\text { science and about science) }\end{array}$ & $\begin{array}{l}\text { p) Prospective science teachers present and discuss their final work. (This consisted of a } \\
\text { lesson plan and associated activities, which were related to a geological theme. The } \\
\text { lesson plan must include a modelling activity and must contribute to the } \\
\text { development of conceptual knowledge, to the development of inquiry skills and also } \\
\text { to the understanding of the nature of models and of the nature of science). }\end{array}$ \\
\hline
\end{tabular}

Adapted from Torres and Vasconcelos (2016a)

paper, in the subject of geoscience education, which took place in the first year of their master's programme. With this intervention programme we tried to develop the consensus view of NOS (Abd-El-Khalick, 2006; Lederman et al., 2002) that was previously described in the theoretical background section and to improve prospective science teachers' views regarding models in science (Chamizo, 2013; Giere, 2010; Oh \& Oh, 2011) and for teaching (Justi \& Gilbert, 2002, 2003; Oh \& Oh, 2011).

As formerly described, an explicit and reflective NOS instruction is considered to be effective (Akerson, AbdEl-Khalick, \& Lederman, 2000; Koksal, Cakiroglu, \& Geban, 2013; Mesci \& Schwartz, 2017; Wahbeh \& Abd-ElKhalick, 2014), being the history of science (Acevedo-Díaz, García-Carmona, \& Aragón, 2016; Pavez, Vergara, Santibañez, \& Cofré, 2016; Torres \& Vasconcelos, 2015), as well as the use of models and historical models crucial for a better understanding of NOS (Halloun, 2007; Oh \& Oh, 2011; Torres \& Vasconcelos, 2017). In this way, NOS aspects were taught explicitly, by relying on history of science, models and historical models and activities were designed in order to promote reflection and debate.

Before and after the intervention programme, questionnaires and interviews (Appendixes A and B) were administered to the prospective science teachers. Their views of NOS were analysed with the help of the Q.S.R. 
Table 2. Prospective teachers' views of nature of science, before (Pre) and after (Post) the intervention programme

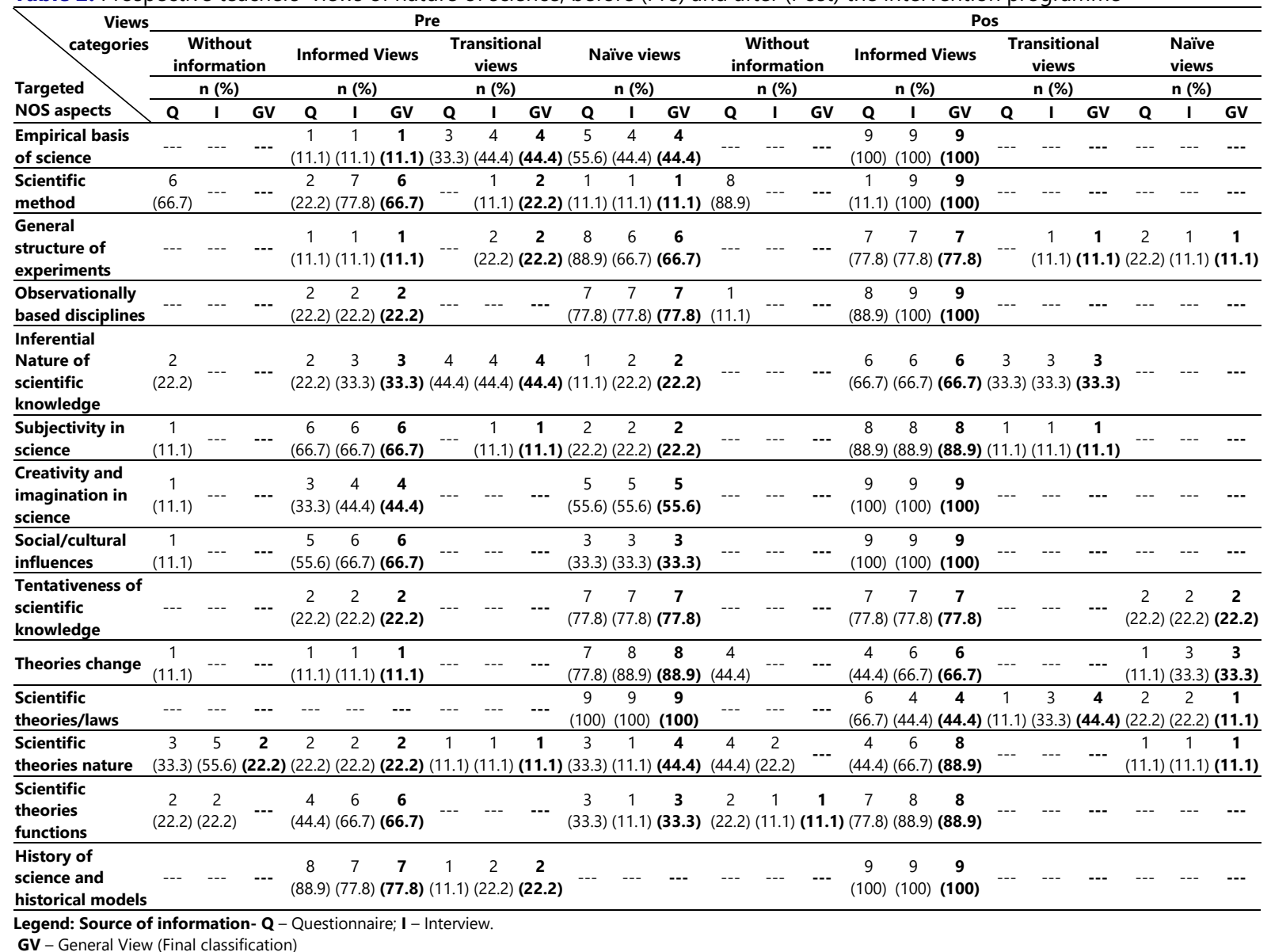

NVivo 10 qualitative data analysis package, regarding specific NOS aspects, which were previously defined (see Table 2). Their views were compared with the contemporary conceptions of NOS (which were described in the theoretical background) and classified as "naïve", "transitional" and "informed" categories. Informed views of NOS match current conceptions of NOS aspects, while naïve views do not. Transitional views were those that reflect emerging conceptions of some NOS aspects, for example, when participants show informed views only in a few (not all) questions regarding each NOS aspect (they simultaneously show arguments that were aligned, and others that were not aligned, with currently accepted conceptions). The category "without information" is related to those few cases in which participants did not address the aspect under analysis (Table 2). In order to analyse both questionnaires and interviews, a coding grid, which was already used in a previous study, was developed by the authors (Torres \& Vasconcelos, 2016b). Questionnaires and interviews were analysed according to this coding grid by each author separately. When discrepancies were found, the authors discussed until a consensus is reached.

The lesson plans constructed in the end of the intervention programme were also analysed according to a previously validated grid. It was analysed which NOS aspects were incorporated in each lesson plan, how they were planned to be addressed and if it is supposed to use models and for what purpose.

\section{Instruments}

In order to evaluate how the intervention programme influenced prospective teachers' views of NOS, a questionnaire and an interview (Appendixes A and B) were administered before and after the intervention programme. The questionnaire was adapted from the Views of Nature of Science Questionnaire - Form C (VNOS-C) (Lederman et al., 2002), by revising one question so as to relate more to the respondents' scientific area (question number seven) and by adding two more questions. These two questions allowed us to analyse the relevance that prospective science teachers attribute to history of science and the history of models in science education (question number two), as well as the ways in which the curricular component of the master's degree contributes to framing the views on NOS by prospective science teachers (question number twelve). Despite the acknowledged validity of VNOS-C, we validated this adapted questionnaire for Portuguese prospective science teachers in a previous study, 
considering the specificity of the sample and the inclusion of different questions. In that study, we verified that questions were understandable and that the respondents addressed the predefined targeted NOS aspects and proved to be capable of presenting a wide range of views. Moreover, by comparing the NOS profiles generated by the separate analyses of the questionnaires and the transcripts of interviews, a high degree of congruence was also achieved. These results constitute evidences regarding the validity of this questionnaire (more details of this process are presented in Torres and Vasconcelos (2016b). Interviews were always conducted after filling out the questionnaire. In the interviews, respondents were asked to read and to better explain and justify certain answers and also to clarify some unclear responses, in order to avoid ambiguities. Indeed, Lederman and collaborators (2002) recommend this follow-up interviews after the administration of the questionnaire. As so, according to the literature review (Abd-El-Khalick, 2006; Abd-El-Khalick et al., 1998; Lederman et al., 2002) and in order to clarify respondents' answers, the main interview protocol was elaborated (Appendix B). These main questions oriented the interview and some other questions were also made given the specificity of the answers of each respondent.

The grid to evaluate the lesson plans was mainly used to check which NOS aspects were included in each lesson plan and how they were planned to be taught (explicitly/implicitly; in an embedded/non-embedded manner); and to check if it was supposed to use models in the class and with what purpose (to develop conceptual knowledge; to develop inquiry skills; and/or to develop NOS views).

\section{RESULTS AND DISCUSSION}

\section{NOS Views}

In Table 2, it is presented prospective science teachers views of NOS before and after the intervention programme. We presented their views according to their answers to the questionnaires (Q), to the interviews (I) and to their general view (that results from their answers to both instruments - GV). Our analysis will focus on their general views (GV). As shown in Table 2, prospective science teachers improved their views of NOS after attending the intervention programme. In fact, before the intervention programme several problems were identified, especially related to the empirical, tentative and inferential nature of scientific knowledge, the general structure of experiments and observationally-based disciplines and to the difference between theories and laws and theories change. The following section will present prospective teachers' views of each NOS aspect evaluated, either before or after the intervention programme.

\section{Empirical Basis of Scientific Knowledge}

Before the intervention programme, only one respondent $(11.1 \%)$ possessed an informed view concerning the empirical basis of scientific knowledge. In fact, four respondents believed that science is based on facts and concrete things, emphasising the need for experiments in the development of scientific knowledge. The other four presented a transitional view, i.e., they simultaneously presented arguments that were aligned and others that were not aligned with the currently accepted conception of the empirical basis of scientific knowledge. In this regard, Vera stated:

$$
\begin{aligned}
& \text { In my opinion, the development of scientific knowledge requires experiments, as theoretical scientific } \\
& \text { knowledge must be tested through experiments in order to prove or disprove the theory. } \\
& \text { (Pre_Questionnaire_PreQ_Vera) } \\
& \text { I think that imagination is important, as if we just stick to data, we are not able to make new } \\
& \text { interpretations and we are not able to discover the key point. With imagination we can make inferences, } \\
& \text { beyond what is there, that may be even more important." (Pre_Interview_PreI_Vera) }
\end{aligned}
$$

After the intervention programme, all prospective teachers held informed views of the empirical nature of scientific knowledge. In fact, they recognized that experiments are not always needed in the development of scientific knowledge and that science is the result of a human endeavour to explain the world (Table 3). 
Table 3. Examples of prospective teachers' views of nature of science, before (Pre) and after (Post) the intervention programme NOS aspects Examples

\begin{tabular}{|c|c|c|}
\hline & \\
\hline & Pre & Pos \\
\hline $\begin{array}{l}\text { Empirical basis } \\
\text { of science }\end{array}$ & $\begin{array}{l}\text { Science is based on facts and concrete things, while other disciplines are } \\
\text { influenced by individuals (...). } \\
\text { Scientific knowledge requires experiments. We need to conduct experiments } \\
\text { for the development of scientific knowledge. } \\
\text { Q (questionnaire)_Francisco (Uninformed) }\end{array}$ & $\begin{array}{l}\text { Science differs from other disciplines because, although it is } \\
\text { based on interpretations, scientific disciplines try to explain } \\
\text { phenomena and processes of nature. } \\
\text { Q_Francisco (Informed) } \\
\text { No, the development of scientific knowledge is not based } \\
\text { solely on experiments. } \\
\text { I (interview)_Francisco (Informed) }\end{array}$ \\
\hline $\begin{array}{l}\text { Scientific } \\
\text { method }\end{array}$ & $\begin{array}{l}\text { In science there is no single scientific method and there is always some } \\
\text { subjectivity of the scientist. } \\
\text { Q_Sofia (Informed) } \\
\text { I think that there is no single scientific method; I think that there are many } \\
\text { methods to achieve something. }\end{array}$ & $\begin{array}{l}\text { No [I do not think that scientists use a specific method when } \\
\text { they do science]. As science is subjective, I think that there } \\
\text { isn't a general guide that should be followed by all scientists } \\
\text { (...) there are different ways to reach the same conclusion } \\
\text { I_Inês (Informed) }\end{array}$ \\
\hline
\end{tabular}

I_Sofia (Informed)

Yes, I think that, in order to construct scientific knowledge, we must employ

the scientific method, in terms of a certain stepwise procedure

I_Francisco (Uninformed)

General An experiment is a practical activity performed to prove or disprove a

structure of scientific theory.

experiments Q_Vera (Uninformed)

Yes, I believe that there is no need to manipulate variables in an experiment.

An observation may constitute an experiment.

I_Vera (Uninformed)

Observationally The development of scientific knowledge, depending on the topic, doesn't

based always rely on experiments; that is, there is scientific knowledge which was

disciplines only based on observation (and with no need to rely on experiments).

Q_Maria (Informed)

[An experiment] is mainly based on the manipulation of

variables with the aim of observing and collecting data and

evidence which allow us to take conclusions and to respond

to the objective/central question of the situation.

Q_Inês (Informed)

Not always. Because there are scientists that develop

theories based only on observations.

Q_Maria (Informed)

No, I don't think so [that the development of scientific

In my opinion, the development of scientific knowledge requires experiments, knowledge requires experiments] (...) knowledge can be as theoretical scientific knowledge must be proven through experiments in developed through direct observations, it doesn't need order to prove or disprove a theory. Theories are only scientifically valid after experiments. (...) Yes, my view has changed a little [since I being tested with experiments.

Q_Vera (Uninformed) I_Vera (Informed)

\begin{tabular}{ll}
\hline Inferential & With the increase of technology that allows the exploration of remote places \\
Nature of & of the Earth, I think that it is possible to do research about the different layers
\end{tabular} of the Earth, I think that it is possible to do research about the different layers
of the Earth's interior. Q_Inês (Uninformed)

scientific

knowledge (...) Through the data that they collect in the field, when they go to the sites, they remove samples and, according to those samples, the composition of those samples, I think that they try to elaborate the structure of the interior of the Earth.

I_Inês (Uninformed) Scientists are not completely certain about the Earth's interior, as they do not species definition.
use direct data; they use inferred data (for example, data from seismic waves I_Vera (Informed) propagation). (...) Scientists are certain concerning species definition (...).

Q_Vera(Transitional)

\begin{tabular}{ll}
\hline Subjectivity in & I think that the method of an exact science is more objective and will produce \\
science & more concrete answers. Philosophy, for example, is based on people' \\
& opinions, so there aren't correct answers in philosophy. \\
& There are two hypotheses (... ) that occurred at the same time and that were \\
& strong enough to lead to the extinction of species (...) Despite both being \\
correct, it is not possible that one invalidates the other, as we are not certain \\
of anything. \\
I_Carolina (Uninformed)
\end{tabular}

Creativity and In my opinion, scientists use imagination and creativity in two stages. In the imagination in planning stage, as the selection of the theme is crucial, that should bring science something new to science. After data collection, imagination is important, because there is a need to make inferences from the data obtained.

Q_Vera (Uninformed)

Scientists use their imagination and creativity after data collection, as they try

to make sense of the data collected.

Q_Bárbara (Uninformed) responded to the first questionnaire

have said that scientists are not absolutely certain about from inferences and not from direct observations. As such, it might be influenced by whom is doing the inferring from the data. Also, scientists are not totally certain about the concept of species. (...) My view has changed as in the former questionnaire I said that they were certain regarding

\author{
I_Vera (Informed)
}

With the same data, same things, different conclusions are possible because we are talking about people and people are subjective. Also, by selecting certain hypotheses instead of others, by manipulating certain variables instead of others, they are influencing the research, as they are subjective and they use their imagination. As a result it is obvious that they can reach different conclusions. I_Rita (Informed)

Yes, scientists use imagination and creativity, especially when they formulate questions and also after data collection. To formulate questions, scientists must imagine or expect possible results and in the end they have to explain the results obtained. (...) [Imagination and creativity] y are mainly used on these stages, but scientists use imagination and creativity in all stages of their investigations.

I_Bárbara (Informed)

Social/cultural I think that science is universal, as water freezes at $0^{\circ} \mathrm{C}$ in Portugal and in influences Japan or in Antarctic. Science should be the same for all, as well as theories and experiments.

Q_Francisco (Uninformed)

Yes, I consider that science reflects social and cultural values. As I have mentioned before, the environment where scientist live may influence its knowledge concerning a certain aspect.

I consider that science reflects social and cultural values, as we are influenced by those values. (...) We are all influenced, depending on the region. For example, I behave in a different way from a person from Afghanistan; our points of view are completely different. And yes, science will be influenced by my educational background, by my empirical experience; all of this will influence me as a scientist... I think so. I_Maria (Informed)

\title{
I_Francisco (Informed)
}

Yes, science reflects social and cultural values as we are integrated in a society and culture. We belong to that y society and culture, as our personality is built in that environment. This will influence our interpretation of and even our questioning towards reality. I_Sofia (Informed) 
Table 3 (continued). Examples of prospective teachers' views of nature of science, before (Pre) and after (Post) the intervention programme

\begin{tabular}{|c|c|c|}
\hline \multirow[t]{2}{*}{ NOS aspects } & \multicolumn{2}{|l|}{ Examples } \\
\hline & Pre & Pos \\
\hline $\begin{array}{l}\text { Tentativeness } \\
\text { of scientific } \\
\text { knowledge }\end{array}$ & $\begin{array}{l}\text { Scientific theories change over the course of time (...). A scientific law is } \\
\text { established as a universal truth and it is something that is accepted by the } \\
\text { entire scientific community, such as the law of gravity. On the other hand, a } \\
\text { theory tries to explain something without been recognized a truth, like, for } \\
\text { example, the theory of evolution. } \\
\text { Q_Vera (Uninformed) }\end{array}$ & $\begin{array}{l}\text { I believe that scientific theories change and may be } \\
\text { reformulated. They are not eternal for many reasons (...). } \\
\text { A law describes something that we observe repeatedly (...), } \\
\text { while a theory is something more comprehensive. A theory } \\
\text { was accepted by the scientific community (...) } \\
\text { I_Rita (Informed) }\end{array}$ \\
\hline $\begin{array}{l}\text { Theories } \\
\text { change }\end{array}$ & $\begin{array}{l}\text { These changes may occur, for example, because technology has advanced } \\
\text { and now there are new means that demonstrate that the former conception } \\
\text { was not the correct one. } \\
\text { Q_Vera (Uninformed) }\end{array}$ & $\begin{array}{l}\text { I believe that scientific theories change and may be } \\
\text { reformulated. They are not eternal for many reasons... or } \\
\text { due to new observations, or due to new results in } \\
\text { experiments, or due to scientists' creativity and imagination. } \\
\text { Someone may think in something different, as a } \\
\text { consequence things may be reformulated. } \\
\text { __Rita (Informed) }\end{array}$ \\
\hline $\begin{array}{l}\text { Scientific } \\
\text { theories/laws }\end{array}$ & $\begin{array}{l}\text { A theory is something that may undergo changes, while a law is something } \\
\text { concrete and immutable. } \\
\text { Q_Francisco (Uninformed) } \\
\text { I think that a law is something that is proven; a theory is something that we } \\
\text { suppose. (...) I think that a theory may evolve into a law. } \\
\text { Q_Andreia (Uninformed) }\end{array}$ & $\begin{array}{l}\text { A scientific theory intends to explain phenomena or } \\
\text { processes that occur in nature. A scientific law is based on } \\
\text { observable/experimental patterns (...). Gravity law - all } \\
\text { objects are submitted to gravity, which is responsible for } \\
\text { their downward movement. Tectonic plates movement - it } \\
\text { explains how the movement of tectonic plates occur and } \\
\text { which factors influence this movement. } \\
\text { Q_Maria (Informed) }\end{array}$ \\
\hline $\begin{array}{l}\text { Scientific } \\
\text { theories nature }\end{array}$ & $\begin{array}{l}\text { A scientific theory may be what is proposed as an explanation for certain } \\
\text { phenomena, structures and actions. (...) Accepted theories represent what is } \\
\text { known at the moment and give us a well-founded explanation of what exists. } \\
\text { Q_Carolina (Informed) } \\
\text { Theories may change because they are not facts. So, they are hypotheses that } \\
\text { may prove to be erroneous. } \\
\text { Q_Andreia (Uninformed) } \\
\text { (...) Theories are suppositions (hypotheses) of what happens. } \\
\text { Q_Bárbara (Uninformed) }\end{array}$ & $\begin{array}{l}\text { (...) and theories explain those scientific laws, they are not } \\
\text { hypotheses. } \\
\text { I_Bárbara (Informed) } \\
\text { Theories are suppositions, probable ideas. Laws are theories } \\
\text { that are scientifically accepted by the scientific community. } \\
\text { Q_Andreia (Uninformed) } \\
\text { For example, the theory of plate tectonics, that tries to } \\
\text { explain the movement of the tectonic plates. } \\
\text { Q_Francisco (Informed) }\end{array}$ \\
\hline $\begin{array}{l}\text { Scientific } \\
\text { theories } \\
\text { functions }\end{array}$ & $\begin{array}{l}\text { We bother to learn scientific theories because we are very curious and we } \\
\text { wonder ourselves about the world. } \\
\text { Q_Sofia (Uninformed) } \\
\text { It is important to learn scientific theories not only to understand the world } \\
\text { but also because a theoretical framework is always needed in order to } \\
\text { conduct research projects. } \\
\text { Q_Vera (Informed) }\end{array}$ & $\begin{array}{l}\text { Because it is important to reach more completed theories, } \\
\text { based on theories that are not completely correct. } \\
\text { I_Andreia (Informed) }\end{array}$ \\
\hline $\begin{array}{l}\text { History of } \\
\text { science and } \\
\text { historical } \\
\text { models }\end{array}$ & $\begin{array}{l}\text { History of Science is important [in science education], as it is possible to verify } \\
\text { that science is not dogmatic and that current scientific knowledge is achieved } \\
\text { through the contributions of several scientists of the past. } \\
\text { I_Maria } \\
\text { Yes, historical models are also important [in science education] as they } \\
\text { facilitate the learning and the transmission of content knowledge. Just saying } \\
\text { that "the nucleus of the cell contains this and that" is very different from } \\
\text { explaining it with a model that students may observe. } \\
\text { I_Maria (Transitional) }\end{array}$ & $\begin{array}{l}\text { Both history of science and historical models are very } \\
\text { important [in science education] as they explain how science } \\
\text { changes over the course of time; they demonstrate } \\
\text { scientists' ideologies and beliefs in the past. (...) In this way, } \\
\text { students will understand that science is not a dogma and it } \\
\text { depends on cultural, economic, technological and social } \\
\text { aspects of that time. } \\
\text { Q_Maria (Informed) } \\
\text { Employing content related to history of science and } \\
\text { historical models in science education allows students to } \\
\text { develop an in-depth view about science, its evolution, its } \\
\text { characteristics and its nature. } \\
\text { Q_Vera (Informed) } \\
\text { To understand the history and evolution of science is } \\
\text { essential to understand what we known and how we achieve } \\
\text { that knowledge. To understand that several contexts have } \\
\text { influenced science, it helps us to understand how science is } \\
\text { constructed. } \\
\text { Q_Rita (Informed) }\end{array}$ \\
\hline
\end{tabular}

The results were globally positive concerning the empirical basis of scientific knowledge. One prospective science teacher maintained an informed view about this aspect, while the other eight have improved it.

\section{Scientific Method}

When asked about the existence of a single scientific method, the majority of respondents $(6-66.7 \%$ - before the intervention programme and $9-100.0 \%$ - after the intervention programme) recognized that there are different ways of doing science. Despite the number of informed answers given before the intervention programme, it was verified that prospective science teachers improved their views concerning the (in)existence of a single scientific method. In fact, three prospective science teachers improved their views about this aspect and the other six have maintained an informed view. 


\title{
General Structure of Experiments
}

Before the intervention programme, the majority of prospective science teachers revealed some difficulties in describing an experiment. In fact, only one respondent presented an informed view concerning the general structure and aim of an experiment. However, after the intervention programme, seven of them (77.8\%) recognized the manipulative nature and aim of experiments. In fact, only one respondent maintained an uninformed view. Seven have improved their views and one has maintained his informed view about this aspect. For example, Inês stated:

An experiment consists of a manipulation of variables of an object, phenomena or process that occurs in the real world and I think that we may verify the causes and effects, the object of the study may acquire different behaviours under different situations. (PosI_Inês)

\section{Observationally based Disciplines}

Concerning the relevance of observationally based disciplines in science, only two prospective science teachers held an informed view prior to the intervention programme (for example Maria - see Table 3). However, after the intervention programme all respondents understood the relevance of observation in science and that experiments are not always required to develop scientific claims, which ultimately means that seven prospective science teachers have improved their views about this aspect.

\section{Inferential Nature of Scientific Knowledge}

Only three (33.3\%) prospective science teachers had a full understanding of the inferential nature of scientific knowledge before the intervention programme. Two of them presented naïve views and four (44.4\%) transitional views, as they recognized the inferential nature of scientific knowledge only in some situations. In this regard, Andreia stated:

\begin{abstract}
Scientists are not totally certain, as the information that they obtain from the interior of the Earth does not come from direct observation, but from indirect data (...) Scientists are certain concerning species definition, as they have conducted experiments that enable scientists to analyse singularities of each organism and group them in distinct species. (PreQ_Andreia)
\end{abstract}

After the intervention programme, the majority of respondents $(n=6)$ recognized that indirect evidence is used to determine structures and models, such as the Earth's interior model. They further indicated that species is a construct (which is not certain) that helps scientists to organize, classify and establish relationships between organisms. For example, Vera stated:

\section{I think that the concept of species emerges from the need to group organisms, due to the variety of organisms that exist, it is more related to the need scientists have to group organisms in order to facilitate their work. (PosI_Vera)}

Regarding this aspect, five prospective science teachers improved their views, three of them maintained an informed view and one maintained a transitional view.

\section{Subjectivity in Science}

In spite of the verified improvement of prospective science teachers' understanding regarding subjectivity in science, the majority of them presented informed views either before or after the intervention programme (Table 2), recognizing the influence of scientists' knowledge, background, expectations and opinions in science. In this way, they believed that subjectivity may explain the dinosaur extinction controversy and thus why different conclusions are possible. However, before the intervention programme, two respondents surmised that this controversy results simply from the scarcity of data and did not give any relevance to subjectivity in science. In general terms, six prospective science teachers maintained an informed view, while three of them improved their views concerning subjectivity in science.

\section{Creativity and Imagination in Science}

Although all prospective science teachers had previously recognized that creativity and imagination are relevant to the development of scientific knowledge, the majority of them $(n=5-55.6 \%)$ believed that creativity and imagination are linked only to certain stages of the research, namely the planning stage and the stage after data 
collection (see Table 3). After the intervention programme, all prospective science teachers held informed views concerning creativity and imagination in science, highlighting their use in every stage of the research:

Creativity and imagination are very important in scientific research. For example, when constructing a model (...) (PosQ_Francisco)

[Scientists] use imagination and creativity, as they are human beings. Imagination and creativity are used in all stages of the research, such as the formulation of questions, the formulation of hypotheses, the experiment (that can be performed in very different ways), the formulation of conclusions and of a final theory (...). (PosI_Rita)

Moreover, it is emphasised that creativity and imagination are fundamental in science as they

“(...) allow the evolution and enables the progress (...) [scientists] are creating something, therefore they need creativity and imagination" (PosI_Sofia)

In the end, five prospective science teachers improved their views and four of them maintained an informed view concerning this aspect.

\section{Social and Cultural Influences}

The majority of respondents $(66.7 \%-\mathrm{n}=6$ - before the intervention programme and $100.0 \%$ after it) held informed views concerning social and cultural influences on science, as they recognized the influence of social and cultural aspects on science development. In this case, three prospective science teachers have improved their views concerning this aspect.

\section{Tentativeness of Scientific Knowledge}

Despite the fact that all prospective science teachers assumed that theories change, the majority of them ( $n=7$; $77.8 \%$ ) held the naïve view that laws are more certain than theories, suggesting a certain lack of knowledge concerning the tentativeness of scientific knowledge. Furthermore, five prospective science teachers $(55.6 \%)$ mentioned that laws are absolute and do not change.

After the intervention programme, the majority of prospective science teachers improved their views concerning the tentativeness of scientific knowledge. In fact, only two prospective science teachers persisted with the view that laws are more certain than theories. For example, Andreia still mentioned:

Yes, I said that theories are assumptions, probable ideas and that laws are theories that are scientifically accepted (...) theories can still be tested, laws are typically proven. (PosI_Andreia)

Although two prospective science teachers maintained an uninformed view, five of them have improved their views, while two maintained their informed view about the tentativeness of scientific knowledge.

\section{Theories Change}

When analysing why theories change, we also verified that prospective science teachers improve their views, as only one prospective teacher presented informed views prior to the intervention programme. In fact, they mainly mentioned that theories change due to technological advances and new knowledge (Table 3). On the other hand, after the intervention programme, the majority of respondents held informed views, recognising the role of different interpretations and perspectives in the development of scientific knowledge. In fact, only three prospective science teachers have kept an uninformed view, as five others have improved their views, having one maintained his informed view.

\section{Difference between Scientific Theories and Laws}

Prior to the intervention programme, all prospective science teachers presented naïve views regarding the difference between scientific theories and laws. Indeed, seven respondents (77.8\%) indicated that laws are more certain than theories and two of them also added that theories evolve into laws, as they become proven (see examples of Table 3). It was verified that prospective teachers improve their views, as after the intervention programme, four respondents $(44.4 \%)$ possessed informed views and four others transitional views. For example, Vera recognized that "a scientific law constitutes a generalization of patterns that are observed in nature, while a scientific theory provides explanations for those laws (PosQ)". On the other hand, she also believed that laws are 
more certain than theories, which revealed a transitional view. Regarding this aspect, only one respondent has kept an uninformed view while the remaining have improved their views.

\section{The Nature of Scientific Theories}

Only two prospective science teachers held informed views concerning the nature of scientific theory prior to the intervention programme. It is important to emphasize that at this stage of the study prospective science teachers undervalued scientific theories, considering them flawed and less important than laws. In this respect, Vera said:

\section{A theory tries to explain something without being recognized as a truth, like, for example, the theory of evolution. (PreQ_Vera)}

After the intervention programme, the bulk of respondents $(n=8)$ held an informed view, recognising that theories are explanations that have scientific value:

\section{A scientific theory must be approved by the scientific community to be recognized as a scientific theory. (...) scientific theories are explanations which were validated by the scientific community (PosQ_Vera)}

In this case, only one respondent has maintained an uninformed view. Four of them improved their views and two maintained an informed view (for this aspect two prospective science teachers did not give sufficient data to track changes to their profile).

\section{Functions of Scientific Theories}

Concerning the function of scientific theories, the majority of prospective science teachers held informed views both before and after the intervention programme. However, before the intervention programme three respondents had some difficulties in justifying the usefulness of scientific theories. After the intervention programme, eight respondents $(88.9 \%)$ possessed informed views concerning the usefulness of learning scientific theories: $66.7 \%(n=6)$ believed that theories provide a theoretical framework that allows for the understanding of current knowledge; $11.1 \%(n=1)$ recognized that scientific theories provide a theoretical framework for future investigations and $11.1 \%$ $(n=1)$ stated that scientific theories have both functions. In this case, three prospective science teachers improved their views, while five of them maintained an informed view (for this aspect one prospective science teacher did not give sufficient data to track changes to his profile).

\section{The History of Science and Historical Models}

When asked about the relevance of history of science and historical models for science education, the majority of prospective science teachers also presented informed views both before and after the intervention programme. However, we can verify that after the intervention programme they exhibited a better understanding of their relevance for science education, as they improved their views related to historical models. In fact, both Maria and Inês did not understand the full potential of historical models in science education, as their relevance was restricted to the fact that they were visual aids in the learning process. In this way, two prospective science teachers improved their views, while seven maintained an informed view regarding this aspect.

\section{The Change of their Views about Science}

The results related to the last question of the questionnaire (that was only applied after the intervention programme) were already discussed in a previous work (Torres, Amador, \& Vasconcelos, 2016) and are briefly discussed in this paper. In this regard, all respondents recognized that they had changed their views of NOS and had particularized some changes concerning specific NOS aspects. Three respondents (33.3\%) expressed that they had come to a better understanding of the fact that experiments are not always required in the development of scientific knowledge:

\section{I have learned that science involves much more than conducting experiments. (PosQ_Andreia)}

Moreover, two respondents (22.2\%) emphasised that they had improved their views concerning the difference between theories and laws and two others their views related to social and cultural influences on science:

The main change was related to the influence of socioeconomic context in scientific enterprise. In the beginning, I thought that there was no relationship, now I recognize it (PosQ_Vera) 
Another important achievement was the recognition that they had arrived at a better understanding of the relevance of NOS instruction in science classes $(44.4 \%$; $=4)$, which we considered of the utmost importance, considering the nonlinear translation of NOS views to classroom practice. Furthermore, three respondents $(33.3 \%)$ also revealed that they better understood the relevance of using history of science in their classes.

Concerning the sources (or reasons) responsible for the changes that have occurred, all respondents mentioned the classes of the intervention programme and three (33.3) the reading of certain documents, such as scientific papers.

In this way, and considering the results obtained, we may assume that the classes of the intervention programme had positively contributed to the improvement of prospective science teachers' views of NOS. As previously mentioned, NOS aspects were explicitly taught in the classes of the intervention programme and by relying on historical models and history of science. Moreover, some prospective science teachers also rely on historical models and history of science in their lessons plans (Maria, Vera, Sofia and Carolina) to teach NOS aspects to their students, which may indicate that prospective science teachers themselves reckon that historical models and history of science may be used to efficiently teach NOS aspects.

\section{Models Views}

Although models are considered to be an important aspect of science, we decided to analyse in depth prospective science teachers' knowledge about models in another study (Torres \& Vasconcelos, 2017). Globally, we concluded that the prospective science teachers who attended the intervention programme improved their views regarding models in science (both the concept and purposes of scientific models) and for teaching science (as they greatly amplified their views regarding the relevance of models in science teaching).

\section{Lessons Plans}

As prospective science teachers were free to choose a scientific content in the end of the intervention programme, the lessons plans were related to different geology themes: Vera constructed a lesson plan to teach about seismology; Sofia about plate tectonic theory; Rita about coastal erosion; Carolina about sedimentary rocks and environments; Bárbara about geological time; Maria about the structure of the interior of the Earth; Inês about groundwater; Francisco about volcanology and Andreia about rock deformation. The lessons plans were mainly analysed regarding the intention of instructing NOS and the use of models. Although all prospective science teachers included NOS aspects in their lessons plans, there are some differences concerning the number of aspects incorporated in each lesson plan. For example, Inês made only references to the tentativeness of scientific knowledge, while Rita focused on six distinct aspects. For example, Rita had developed a problematic scenario about a real problem in Portugal (coastal erosion) in which she raised many problems and doubts to be answered by the students. Students were prompt to develop a modelling activity regarding coastal erosion, while thinking about the relevance of models in the development of scientific knowledge and in the resolution of problems of everyday life. To complete the activity, students would have to answer different questions related to the phenomenon of coastal erosion, but also to some related with NOS aspects, such as: Could models explain this phenomenon and help in the achievement of answers to those problems? Do you think that the knowledge generated in this activity is immutable? And in science? Maria, who also included many NOS aspects in her lesson plan, asks for a final exercise that prompted students' reflection regarding scientific model characteristics: Please comment the following sentence - Nowadays there are two models of the Earth's internal structure, that divide Earth in concentric layers. These layers present different designations and thicknesses.

The majority of prospective science teachers $(n=8-88.9 \%)$ focused on the tentativeness of scientific knowledge, while none of them focused on the difference between theories and laws (see Table 4). In fact, the difference between scientific theories and laws was the aspect that revealed the fewest informed views before and even after the intervention programme (see Table 2), which may explain why this aspect was not focused on in any lesson plan. Both social and cultural influences on science and the relevance of models in scientific knowledge development were included in the lesson plans of four prospective teachers. For example, Francisco by using a model with honey for students to understand magma viscosity, also problematized why models are important for the evolution of scientific knowledge. 
Table 4. Number of teachers that included each NOS aspect in their lesson plan

\begin{tabular}{lc}
\hline NOS aspects & Number of teachers that included each NOS aspect \\
\hline Tentativeness of scientific knowledge & $8(88.9)$ \\
\hline Empirical basis of science & $2(22.2)$ \\
\hline Subjectivity in science & $3(33.3)$ \\
\hline Creativity and imagination in science & $2(22.2)$ \\
\hline Social/cultural influences & $4(44.4)$ \\
\hline Observation and inferences in science & $2(22.2)$ \\
\hline Inexistence of a single scientific method & $1(11.1)$ \\
\hline Scientific theories/laws & 0 \\
\hline Scientific model meaning & $2(22.2)$ \\
\hline Scientific models characteristics & $2(22.2)$ \\
\hline Relevance of scientific models & $4(44.4)$ \\
\hline
\end{tabular}

All prospective teachers developed lessons plans that required the use of models. All of them intended to use models to promote the development of conceptual knowledge, eight (88.9\%) to promote the development of inquiry skills and only two $(22.2 \%)$ to promote the development of views of NOS. The analysis of the lessons plans also showed the intention of teaching NOS in an embedded (100\%) and explicit (66.7\%) way.

By analysing the lessons plans, it was also possible to verify that prospective science teachers planned to teach NOS aspects that were better understood after the intervention programme. As an example, Francisco improved his view regarding the tentativeness of scientific knowledge, as he stated (after the intervention programme): Yes, science is constantly changing and is subject to change. The need that man has of knowing what is going on around him, lead him to the formulation of explicative theories and models (...) Theories and laws are different types of knowledge (...) One thing is what we observe, and the other tries to explain. Likewise, in his lesson plan, he highlighted, in the problematic scenario about volcanos, that scientific knowledge can change, and he also formulated questions for students regarding this subject. One of the questions is: Do you think that the knowledge concerning the viscosity of magma remained constant over the years of geology studies?

Carolina, who improved her view concerning the subjectivity in science, also planned to develop this NOS aspect with students, by formulating one question: Why did scientists found different explanations for the origin of sedimentary environments?

Rita, who improved her view regarding the social and cultural influences in science, also highlighted in her problematic scenario that: Science is always evolving and tries to solve the problems that affect society and the environment. Moreover, one objective that was described in her lesson plan was: To reckon nature of science aspects throughout the lesson, as for example, the influence of the context in science. In spite of being an objective for the lesson plan, it does not directly mean that this NOS aspect will be correctly focused on class. However, in this study, we only analysed the lessons plans constructed after the intervention programme. We intentionally did not analyse how prospective science teachers translate their views into their real practice, as this issue is too complex and will be examined in detail in another paper.

\section{CONCLUSIONS}

Before the intervention programme, results showed that prospective science teachers hold naïve or transitional views regarding most of the NOS aspects evaluated. These results are consistent with those achieved by Akerson et al. (2000), Wahbeh and Abd-El-Khalick (2014) and Pavez et al. (2016). However, after the intervention programme the majority of them presented informed views concerning almost all aspects of NOS, as, in general terms, prospective science teachers either improved their views or maintained an informed view about NOS. These results are consistent with findings obtained by Mesci and Schwartz (2017) and Herman and Clough (2016). However, the prospective science teachers still struggled with some NOS aspects, for example the difference between theories and laws. In the studies conducted by Mesci and Schwartz (2017) and Wahbeh and Abd-El-Khalick (2014) this aspect was also one that caused many difficulties and has proven to be one of the most problematic to be changed. Tasar (2006) also suggested that Turkish preservice teachers held inadequate views concerning the relation between theories and laws, which, in fact, hindered their full understanding regarding the tentativeness of scientific knowledge.

It is important to emphasize that prospective science teachers themselves recognized that they have changed their views and that they have come to a better understanding of the relevance of NOS instruction in science classes, which may contribute to the translation of their views to their instructional practices. Also, prospective science teachers referred to the classes of the intervention programme and to the reading of documents as the sources for the improvement of their NOS views. 
Although all of them had planned to teach NOS in their lessons plans, prospective science teachers revealed different types of awareness regarding NOS instruction. Also, the least understood NOS aspect was not focused by any of them in their lesson plans, a fact which highlights the need to both better develop the least understood aspects and also, as suggested by Tasar (2006), to further investigate the factors that may influence science teachers' views of NOS. The generalized lack of knowledge regarding the difference between theories and laws on our society (which in many cases is a result of the information provided in textbooks and in science education standard documents) may explain the difficulty of improving science teachers' views about it and of dealing with it in classes. Although the majority of prospective science teachers have recognized the full potential of models in science teaching, only two students planned to use them to teach NOS aspects. This result emphasises the need for preservice science teachers to construct more lesson plans, to analyse if they meet the goals and to discuss them with their supervisors and colleagues. As referred by Kaymakamoğlu (2017), it is fundamental for science teachers to be reflexive in order to improve their practices. In fact, prospective science teachers reveal a good understanding of models' potential, but they do not plan to apply them in an effective way in classes, revealing in some cases a lack of reflexion towards their work and objectives.

Despite these positive results, it is crucial to analyse the factors that influence the translation of their views to their classroom practices. As a result, we will observe their classes during their internship to better understand the factors that intervene in efficient NOS instruction.

\section{LIMITATIONS OF THE STUDY AND PEDAGOGICAL IMPLICATIONS}

Even though the small number of respondents in this study may be considered as a limitation factor, it was possible to gather a vast amount of information regarding each prospective science teacher' views. Moreover, they correspond to all teachers enrolled in this master in the north of Portugal, being representative of the population. The questions that directly asked prospective science teachers about their improvement also present some limitations and should be carefully taken into account, as they really do not evaluate their views. However, considering the positive results obtained with the analyses of the other questions and interviews, the data from these self-report questions support these positive results and convey the idea that prospective science teachers recognize improvements in their views and that they better understand the relevance of teaching NOS and of using history of science in science classes. To achieve stronger and more credible results, it would also be useful to monitor these prospective science teachers and to evaluate their views of NOS (using the same questionnaires and interviews used in this study) for a longer period of time, as it is of the utmost importance to evaluate if they retain an informed view of NOS over time.

Concerning the relevance of improving NOS views amongst students (and future active citizens), we consider it fundamental to improve teachers views of NOS. With this study, we verified that an intervention programme like the one used in this study is effective in improving science teachers' views of NOS. As a consequence, we considered this intervention programme to be useful for prospective science teachers and even for in-service teachers to improve their views regarding NOS. Although we cannot say which strategy was more effective, we verified that an explicit and reflexive NOS instruction combined with the use of models, historical models and history of science played a major role for the improvement of prospective teachers views of NOS. In fact, when asked about the sources (or reasons) responsible for the changes that have occurred, prospective science teachers mentioned the classes of the intervention programme and the reading of documents as their main reasons, without specifying any strategy. Aragón Méndez, Acevedo-Díaz and García-Carmona (2018) also concluded that the critical and reflexive analysis of controversial issues are of the utmost importance for a better understanding of NOS. Nevertheless, more research is needed mainly to analyse the factors that mediate the translation of teachers' views into their practice.

Perhaps, it would also be relevant to adapt this intervention programme in order to apply it to elementary teachers and to evaluate its true impact on students, as elementary teachers play a very important role in conveying an idea of science into children's minds from an early age. Some studies already revealed the positive impact that some intervention programmes had in elementary teachers' NOS views. For example, in a study conducted by Adibelli-Sahin and Deniz (2017), elementary teachers attended 14 face-to-face meetings, using explicit and reflective NOS instruction. In this study, subjects improved their NOS conceptions, highlighting the fact that they understood how to teach NOS in their classrooms. Maeng, Bell, Clair, Gonczi and Whitworth (2018) also developed a four-week summer institute that utilized problem-based learning as the context for teaching NOS concepts, which allowed for many practice, feedback and reflection opportunities. This summer institute has also shown to be effective in improving elementary teachers' NOS understandings. 


\section{ACKNOWLEDGEMENTS}

This work was supported by the Portuguese Foundation for Science and Technology (FCT) under Grant SFRH/BD/85735/2012 (PhD scholarship of the first author).

\section{REFERENCES}

Abd-El-Khalick, F. (2006). Over and over again: College students' views of nature of science. In L.B. Flick, \& N. G. Lederman (Eds.), Scientific inquiry and nature of science (pp. 389-425). The Netherlands: Springer. doi: https:/ / doi.org/10.1007/978-1-4020-5814-1_18

Abd-El-Khalick, F., Bell, R. L., \& Lederman, N. G. (1998). The nature of science and instructional practice: Making the unnatural natural. Science Education, 82(4), 417-436. https://doi.org/10.1002/(SICI)1098237X(199807)82:4<417::AID-SCE1>3.0.CO;2-E

Acevedo-Díaz, J. A., García-Carmona, A., \& Aragón, M. M. (2016). Un caso de historia de la ciencia para aprender naturaleza de la ciencia: Semmelweis y la fiebre puerperal. Revista Eureka sobre Enseñanza y Divulgación de las Ciencias, 13(2), 408-422. https:/ / doi.org/10498/18297 http:/ / hdl.handle.net/10498/18297

Adibelli-Sahin, E., \& Deniz, H. (2017). Elementary teachers' perceptions about the effective features of explicitreflective nature of science instruction. International Journal of Science Education, 39(6), 761-790. https://doi.org/10.1080/09500693.2017.1308035

Akerson, V. L., Abd-El-Khalick, F., \& Lederman, N. G. (2000). Influence of a reflective explicit activity-based approach on elementary teachers' conceptions of nature of science. Journal of Research in Science Teaching, 37(4), 295-317. https:/ / doi.org/10.1002/(SICI)1098-2736(200004)37:4<295::AID-TEA2>3.0.CO;2-2

Aragón Méndez, M. M., Acevedo-Díaz, J. A., \& García-Carmona, A. (2018). Comprensión de estudiantes de bachillerato y de profesorado sobre naturaleza de la ciencia mediante el análisis del caso histórico de "Rosalind Franklin y la estructura del ADN". Paper presented at Encuentros de Didáctica de las Ciencias Experimentales.

Bell, R. L. (2006). Perusing Pandora's box: Exploring the what, when and how of nature of science instruction. In L. B. Flick, \& N. G. Lederman (Eds.), Scientific inquiry and Nature of Science (pp. 427-446). The Netherlands: Springer.

Bell, R. L., Blair, L. M., Crawford, B. A., \& Lederman, N. G. (2003). Just do it? Impact of a science apprenticeship program on high school students' understandings of the nature of science and scientific inquiry. Journal of Research in Science Teaching, 40(5), 487-509. https:/ / doi.org/10.1002/tea.10086

Bell, R. L., Matkins, J. J., \& Gansneder, B. M. (2011). Impacts of contextual and explicit instruction on preservice elementary teachers' understandings of the nature of science. Journal of Research in Science Teaching, 48(4), 414-436. https:// doi.org/10.1002/tea.20402

Bell, R. L., Mulvey, B. K., \& Maeng, J. L. (2016). Outcomes of nature of science instruction along a context continuum: preservice secondary science teachers' conceptions and instructional intentions. International Journal of Science Education, 38(3), 493-520. https:/ / doi.org/10.1080/09500693.2016.1151960

Chamizo, J. (2013). A new definition of models and modelling in chemistry's teaching. Science E Education, 22(7), 1613-1632. https:/ / doi.org/10.1007/s11191-011-9407-7

Cheng, M., \& Lin, J. (2015). Investigating the relationship between students' views of scientific models and their development of models. International Journal of Science Education, 37 (15), 2453-2475. https://doi.org/10.1080/09500693.2015.1082671

Deng, F., Chen, D., Tsai, C., \& Chai, C. S. (2011). Students' views of the nature of science: A critical review of research. Science Education, 95(6), 961-999. https:/ / doi.org/10.1002/sce.20460

Giere, R. N. (2010). An agent-based conception of models and scientific representation. Synthese, 172, 269-281. https://doi.org/10.1007/s11229-009-9506-Z

Halloun, I. A. (2007). Mediated Modeling in Science Education. Science \& Education, 16, 653 -697. https:/ / doi.org/10.1007/s11191-006-9004-3

Hazelkorn, E., Beernaert, Y., Constantinou, C. P., Deca, L., Grangeat, M., et al. (2015). Science education for responsible citizenship. Technical report, European commission.

Herman, B. C., \& Clough, M. P. (2016). Teachers' longitudinal NOS understanding after having completed a science teacher education program. International Journal of Science and Mathematics Education, 14(Suppl 1), 207-227. https://doi.org/10.1007/s10763-014-9594-1 
Irzik, G., \& Nola, R. (2014). New directions for nature of science research. In M. R. Matthews (Ed.), International handbook of research in history, philosophy and science teaching (pp. 999-1021). The Netherlands: Springer. https://doi.org/10.1007/978-94-007-7654-8_30

Justi, R. S., \& Gilbert, J. K. (2002). Science teachers' knowledge about and attitudes towards the use of models and modelling in learning science. International Journal of Science Education, 24(12), 1273-1292. https:// doi.org/10.1080/09500690210163198

Justi, R. S., \& Gilbert, J. K. (2003). Teachers' views on the nature of models. International Journal of Science Education, 25(11), 1369-1386. https:/ / doi.org/10.1080/0950069032000070324

Kaya, E., \& Erduran, S. (2016). From FRA to RFN, or how the family resemblance approach can be transformed for science curriculum analysis on nature of science. Science $\mathcal{E}$ Education, 25, 1115-1133. https:/ / doi.org/10.1007/s11191-016-9861-3

Kaymakamoğlu, S. E. (2017). Science Teachers' Conceptualizations and Implications for the Development of the Professional Development Programs. Eurasia Journal of Mathematics, Science and Technology Education, 13(7), 3301-3314. https:/ / doi.org/10.12973/eurasia.2017.00718a

Kenyon, L., Davis, E. A., \& Hug, B. (2011). Design approaches to support preservice teachers in scientific modeling. Journal of Science Teacher Education, 22(1), 1-21. https:/ / doi.org/10.1007/s10972-010-9225-9

Khishfe, R. (2012). Relationship between nature of science Understandings and argumentation skills: A role for counterargument and contextual factors. Journal of Research in Science Teaching, 49(4), 489-514. https:// doi.org/10.1002/tea.21012

Khishfe, R., \& Abd-El-Khalick, F. (2002). Influence of explicit and reflective versus implicit inquiry-oriented instruction on sixth graders' views of nature of science. Journal of Research in Science Teaching, 39(7), 551-578. https://doi.org/10.1002/tea.10036

Koksal, M. S., Cakiroglu, J., \& Geban, O. (2013). The effect of explicit embedded reflective instruction on nature of science understandings in advanced science students. Journal of Biological Education, 47(4), 208-223. https:/ / doi.org/10.1080/00219266.2013.799080

Lederman, N. G. (2007). Nature of science: Past, present, and future. In S. K. Abell \& N. G. Lederman (Eds.), Handbook of research on science education (pp. 831-879). Mahwah, NJ: Lawrence Erlbaum Associates.

Lederman, N. G., \& Abd-El-Khalick, F. (1998). Avoiding de-natured science: Activities that promote understandings of the nature of science. In W. McComas (Ed.). The nature of science in science education: Rationales and strategies. The Netherlands: Kluwer Academic Publishers. https://doi.org/10.1007/0-30647215-5_5

Lederman, N. G., \& Lederman, J. S. (2014). Is Nature of Science Going, Going, Going, Gone?. Journal of Science Teacher Education, 25(3), 235-238. https:/ / doi.org/10.1007/s10972-014-9386-Z

Lederman, N. G., Abd-El-Khalick, F., Bell, R. L., \& Schwartz, R. S. (2002). Views of nature of science questionnaire: Toward valid and meaningful assessment of learners' conceptions of nature of science. Journal of Research in Science Teaching, 39(6), 497-521. https:/ / doi.org/10.1002/tea.10034

Lederman, N. G., Bartos, S. A., \& Lederman, J. S. (2014). The development, use, and interpretation of nature of science assessments. In M. R. Matthews (Ed.), International handbook of research in history, philosophy and science teaching (pp. 971-997). Dordrecht: Springer. https://doi.org/10.1007/978-94-007-7654-8_29

Maeng, J. L., Bell, R. L., St. Clair, T., Gonczi, A. L., \& Whitworth, B. A. (2018). Supporting elementary teachers' enactment of nature of science instruction: a randomized controlled trial. International Journal of Science Education, 40(18), 2245-2264. https:// doi.org/10.1080/09500693.2018.1528643

McComas, W. F. (1998). The principal elements of the nature of science: Dispelling the myths. In W. McComas (Ed.), The nature of science in science education: Rationales and strategies (pp. 53-70). The Netherlands: Kluwer Academic Publishers. https:/ / doi.org/10.1007/0-306-47215-5_3

McComas, W. F., Clough, M. P., \& Almzroa, H. (1998). The role and character of the nature of science in science education. In W. McComas (Ed.), The nature of science in science education: Rationales and strategies (pp. 3-39). The Netherlands: Kluwer Academic Publishers. https:/ / doi.org/10.1007/0-306-47215-5_1

Mesci, G., \& Schwartz, R. S. (2017). Changing preservice science teachers' views of nature of science: Why some conceptions may be more easily altered than others. Research in Science Education, 47(2), 329-351. https:/ / doi.org/10.1007/s11165-015-9503-9

Moutinho, S., Torres, J., Fernandes, I. \& Vasconcelos, C. (2015). Teaching nature of science through PBL: A study with prospective science teachers. Procedia-Social and Behavioral Sciences Journal, 191, 1871-1875. https://doi.org/10.1016/j.sbspro.2015.04.324 
Oh, P. S., \& Oh, S. J. (2011). What teachers of science need to know about models: An overview. International Journal of Science Education, 33(8), 1109-1130. https:/ / doi.org/10.1080/09500693.2010.502191

Osborne, J., \& Dillon, J. (2008). Science education in Europe: Critical reflections. A report to the Nuffield Foundation.

Pavez, J. M.,Vergara, C. A., Santibañez, D., \& Cofré, H. (2016). Using a professional development program for enhancing Chilean biology teachers' understanding of nature of science (NOS) and their perceptions about using history of science to teach NOS. Science E Education, 25(3), 383-405. https:/ / doi.org/10.1007/s11191016-9817-7

Tasar, M. F. (2006). Probing preservice teachers' understandings of scientific knowledge by using a vignette in conjunction with a paper and pencil test. Eurasia Journal of Mathematics, Science and Technology Education, 2(1), 53-70. https:// doi.org/10.12973/ejmste/75438

Torres, J., \& Vasconcelos, C. (2015). Nature of science and models: Comparing Portuguese prospective teachers' views. Eurasia Journal of Mathematics, Science $\mathcal{E}$ Technology Education, 11(6), 1473-1494. https://doi.org/10.12973/eurasia.2015.1407a

Torres, J., \& Vasconcelos, C. (2016a). Models in Geoscience classes: How can teachers use them? In Vasconcelos, C. (Ed.). Geoscience Education: Indoor and Outdoor. Springer: Switzerland. https://doi.org/10.1007/978-3-31943319-6

Torres, J., \& Vasconcelos, C. (2016b). Views of nature of science: Adaptation of a questionnaire for Portuguese prospective science teachers. Journal of Science Education, 17(2), 48-52.

Torres, J., \& Vasconcelos, C. (2017). Models in science and for teaching science: Data from an intervention programme. International Journal of Learning \& Teaching, 9(1), 308-318. https:/ / doi.org/10.18844/ijlt.v9i1

Torres, J., Amador, F. \& Vasconcelos, C. (2016). Developing prospective science teachers' views of nature of science: The scientific models. In J. Lavonen, K. Juuti, J. Lampiselkä, A. Uitto \& K. Hahl (Eds.), Electronic Proceedings of the ESERA 2015 Conference. Science Education research: Engaging learners for a sustainable future, Part 6 (coed. M. Izquierdo \& V. Vesterinen), (pp. 820-827). Helsinki, Finland: University of Helsinki.

Torres, J., Moutinho, S., \& Vasconcelos, C. (2015). Nature of science, scientific and geoscience models: Examining students and teachers' views. Journal of Turkish Science Education, 12(4), 3-21. https:/ / doi.org/10.12973/tused.10148a

Wahbeh, N., \& Abd-El-Khalick, F. (2014). Revisiting the translation of nature of science understandings into instructional practice: Teachers' nature of science pedagogical content knowledge. International Journal of Science Education, 36(3), 425-466. https:/ / doi.org/10.1080/09500693.2013.786852 


\section{APPENDIX A}

\section{Adaptation of the "Views of Nature of Science Questionnaire", Form C (VNOS-C) (Lederman et al., 2002)}

Question 1. What, in your view, is science? What makes science (or a scientific discipline such as physics, biology, etc.) different from other disciplines of inquiry (e.g. religion, philosophy, or art)?

Question 2. What is the relevance of history of science and historical models for science education?

Question 3. What is an experiment?

Question 4. Does the development of scientific knowledge require experiments?

- If yes, explain why. Give an example to defend your position.

- If no, explain why. Give an example to defend your position.

Question 5. After scientists have developed a scientific theory (e.g., cell theory, evolution theory), does the theory ever change?

- If you believe that scientific theories do not change, explain why. Defend your answer with examples.

- If you believe that scientific theories do change:

(i) Explain why theories change.

(ii) Explain why we bother to learn scientific theories. Defend your answer with examples.

Question 6. Is there a difference between a scientific theory and a scientific law? Illustrate your answer with an example

Question 7. Science textbooks often represent the interior of the Earth as a set of concentric layers with distinct characteristics. How certain are scientists about the structure of the interior of the Earth? What specific evidence, or types of evidence, do you think scientists used to determine how the interior of the Earth looks like?

Question 8. Science textbooks often define a species as a group of organisms that share similar characteristics and can interbreed with one another to produce fertile offspring. How certain are scientists about their characterization of what a species is? What specific evidence do you think scientists used to determine what a species is?

Question 9. It is believed that about 65 million years ago the dinosaurs became extinct. Of the hypotheses formulated by scientists to explain the extinction, two enjoy wide support. The first, formulated by one group of scientists, suggests that a huge meteorite hit the Earth 65 million years ago and led to a series of events that caused the extinction. The second hypothesis, formulated by another group of scientists, suggests that massive and violent volcanic eruptions were responsible for the extinction. How are these different conclusions possible if scientists in both groups have access to and use the same set of data to derive their conclusions?

Question 10. Some claim that science is infused with social and cultural values. That is, science reflects the social and political values, philosophical assumptions, and intellectual norms of the culture in which it is practiced. Others claim that science is universal. That is, science transcends national and cultural boundaries and is not affected by social, political, and philosophical values, and intellectual norms of the culture in which it is practiced.

- If you believe that science reflects social and cultural values, explain why and how. Defend your answer with examples.

- If you believe that science is universal, explain why and how. Defend your answer with examples.

Question 11. Scientists perform experiments/investigations when trying to find answers to the questions they put forth. Do scientists use their creativity and imagination during their investigations?

- If yes, then at which stages of the investigations do you believe that scientists use their imagination and creativity: planning and design; data collection; after data collection? Please explain why scientists use imagination and creativity. Provide examples if appropriate.

- If you believe that scientists do not use imagination and creativity, please explain why. Provide examples if appropriate.

Question 12. Reflecting upon the classes you have attended this academic year, do you feel as though you have changed your views of the nature of science?

- If yes, identify and explain the main changes and the most important reasons for, and sources of, those changes.

\section{APPENDIX B}

\section{VNOS Interview Protocol}

1. Can you read and better explain your answer?

2. What do you mean by $(\ldots)$ ?

3. How does your answer to question a relates to your answer to question $b$ ?

4. Can you provide some examples that better illustrate your answer?

5. Have your views changed since you responded to the first questionnaire? If so, how?

6. (..)

\section{http://www.ejmste.com}

